Article

\title{
Environmental and Economic Constraints on the Use of Lubricant Oils for Wind and Hydropower Generation: The Case of NATURGY
}

\author{
Gabriel A. González-Reyes ${ }^{1,+}$, Susana Bayo-Besteiro ${ }^{2, *,+} \mathbb{C}^{\text {, Jordi Vich Llobet }}{ }^{3,+}$ \\ and Juan A. Añel ${ }^{2,+}$ (D) \\ 1 Universidade de Vigo, 36310 Vigo, Spain; gonzalezreyesgabriel17@gmail.com \\ 2 EPhysLab \& CIM, Universidade de Vigo, 32004 Ourense, Spain; j.anhel@uvigo.es \\ 3 Naturgy, 28033 Madrid, Spain; jvich@globalpower-generation.com \\ * Correspondence: sbayo@uvigo.es; Tel.: +34-988-387-427 \\ + These authors contributed equally to this work.
}

Received: 24 March 2020; Accepted: 17 May 2020; Published: 21 May 2020

check for updates

\begin{abstract}
Lubricant oil is an essential element in wind and hydropower generation. We present a lifecycle assessment (LCA) of the lubricant oils (mineral, synthetic and biodegradable) used in hydropower and wind power generation. The results are given in terms of energy used, associated emissions and costs. We find that, for the oil turbines and regulation systems considered here, biodegradable oil is a better option in terms of energy and $\mathrm{CO}_{2}$ equivalent emissions than mineral or synthetic oils, from production and recycling through to handling. However, synthetic and mineral oils are better options due to the potential risks associated with the use of biodegradable oil, generally when it comes into contact with water. There are also significant savings to be made in the operation of wind turbines when using an improved type of synthetic oil.
\end{abstract}

Keywords: lubrication; oil; hydropower; wind turbine; $\mathrm{LCA}$; $\mathrm{CO}_{2}$ emissions; cost

\section{Introduction}

Taken together, wind and hydropower provide the greatest proportion of all renewable energies to the grid in Spain, contributing 49.5\% and 34.20\%, respectively, in 2018 [1]. At $178.8 \mathrm{GW}$, wind power represents $18.8 \%$ of the total installed power generation capacity in the European Union (EU), and, with an installed capacity of $23.5 \mathrm{GW}$ [2,3], Spain is second only to Germany in this respect. In terms of hydropower, Spain is ranked twentieth in the world and the fifth in the EU with a total installed capacity of $17.08 \mathrm{GW}$ [4].

One of the critical elements in both technologies is the oil used for lubrication. The potential drawbacks related to the use of lubricant oil include the need to change it regularly, which entails a break in generation and can cause significant economic losses, given the direct impact on the number of working hours of generation and related maintenance issues. Furthermore, in environmental terms, lubricant oil must be managed as a dangerous waste, with inherent risks of spillage during handling.

In a hydropower plant, lubricant oil is used both in turbines and for the regulation of mechanical systems. A turbine transforms potential energy into kinetic energy, which causes the electric generator to rotate. This rotation transforms the kinetic energy into electrical power. The turbine-generator group is made up of static and rotating parts. The bearings are an essential element in the system and are submerged in lubricant oil to avoid premature wear due to friction. In this sense, a thin layer of lubricant oil is the only thing that separates the fixed and rotating elements. The regulatory system consists of pipes that contain lubricant oil, which adjust the movement of mechanical elements through 
the increase or decrease of pressure. The regulatory system of the turbine-generator include tanks that contain between 3000 and 80,000 L [5] of oil.

One of the critical parts of the wind turbine is the gearbox, which consists of a gear assembly that increases the speed of the shaft. The shaft connects the input with the output of the wind turbine. At the same time, the gearbox is the part that suffers the most significant mechanical loss. To minimise the friction within the gear assembly and improve its performance, the gears are submerged in lubricant oil. A gearbox uses between 200 and $400 \mathrm{~L}$ of oil [6,7], depending on the size of the wind turbine. As in the case of hydropower generation, any problem that causes the wind turbine to stop leads to an economic loss.

To be able to adapt to the needs of each application, lubricant oils are required to have particular characteristics and properties. Lubricant oils are made of a base, which is usually between $75 \%$ and 95\% oil. The remaining 5\% consists of the additives that are responsible for determining the final characteristics of the oil. In this work, we follow the oil classification standard in the industry, to make it useful for stakeholders. This classification is based on the type of base oil utilised for the formulation of products [8]:

- Mineral oil-based lubricants

- Synthetic oils

- Biodegradable, environmentally friendly oils (based on esters or fatty oils)

The mineral oil is a direct petroleum by-product usually produced in petrochemical plants. This kind of oil is the primary oil used in regulation and lubrication of turbines in hydropower plants. Synthetic oils can be based on several types of chemical compounds such as esters, diesters, polyalphaolefins, polyalkeleneglycols, silicones, alkyl benzenes or polyphenyl ethers [8]. Synthetic oil has a higher viscosity than mineral oil, and this is important given the high stress in the gears.

It is possible to formulate biodegradable oils from both selected mineral base oils and synthetic oils. However, vegetable oils and synthetic ester-based products are regarded as highly biodegradable and are preferred in those applications where spillage in soil and water is expected [8]. However, it has a disadvantage in that, if it is mixed with water, the oil breaks down more quickly than other mineral oils, which then affects the mechanical elements; it is also more expensive than mineral oil.

There exist studies on the impact of the use of different oils on the performance of the gearbox [9] of a wind turbine. In addition, there exist works that evaluate the $\mathrm{CO}_{2}$ emissions associated with wind power plants [10]. However, studies combining both issues are more difficult to find. Therefore, to address this gap, here we undertake an analysis based on the evaluation of the different lubricant oils described above. We present a lifecycle assessment (LCA) [11] for each one of their applications.

To this end, we use as a case study two hydropower plants and wind farms in Spain owned by Naturgy Energy Group S.A. [12], representing a broad range of hydropower and wind farm facilities. Naturgy is a multinational energy company with a generation mix of $12.6 \%$ hydropower and $8.6 \%$ wind power. In the following sections, we describe the data sources used in this study; we then present the results, followed by a discussion, before finally offering some key conclusions for policy makers and other interested parties.

\section{Data and Methodology}

For the LCA described here, the input data were obtained from the sources listed in Table 1. Naturgy uses mineral oil for regulation in hydropower plants, synthetic oil in wind turbines (specifically in the gearbox) and biodegradable oil for particular applications where there is a danger of spillage, for example in the cleaning grille of the hydropower plant. 
Table 1. Data and sources.

\begin{tabular}{ll}
\hline \multicolumn{1}{c}{ Source } & \multicolumn{1}{c}{ Type of Data } \\
\hline Naturgy (personal communication) & Consumption and price of oil \\
\hline Oil manufacturer: Cepsa [13] & $\mathrm{CO}_{2}$ emissions of production \\
\hline Wind turbine manufacturer: Vestas [14] & Data of wind turbine model V90-20MW \\
\hline $\begin{array}{l}\text { Spanish Association of providers } \\
\text { of petroleum products (AOP) [15] }\end{array}$ & $\begin{array}{l}\text { Energy used in the extraction and } \\
\text { transport of crude oil }\end{array}$ \\
\hline $\begin{array}{l}\text { Ministry of Ecological Transition } \\
\text { of Spain (MITECO) [16] }\end{array}$ & Data on emission factors \\
\hline $\begin{array}{l}\text { Oil stockholding agency } \\
\text { of Spain (CORES) [17] }\end{array}$ & Data of refining and processing of crude \\
\hline $\begin{array}{l}\text { According to SIGAUS [18] and based on } \\
\text { data from the US Department of Energy Management [19] }\end{array}$ & $\begin{array}{l}\text { Data on energy consumption in the } \\
\text { transport and recycling of oil }\end{array}$ \\
\hline
\end{tabular}

For the LCA, we followed the methodology recommended by UNE-EN ISO 14040:2006 [20]. Assessment of the environmental and economic impacts focused on comparative analysis of different types of oil. To study the lubricant oil in a hydropower plant, we assessed the lubrication of the bearings and the regulation system. For the wind turbines, we assessed the lubrication of the gearbox. The main factors considered were the energy used in manufacturing and recycling, changes of equipment required due to wear, types of oils, the amount of waste produced when replacing them, reduction of the potential impact in case of spillage, transport, power generation, $\mathrm{CO}_{2}$ emissions and the cost of each type of oil. Table 2 summarises the relevant information.

Table 2. Processes considered in the LCA for each lubricant oil.

\begin{tabular}{lccc}
\hline \multicolumn{1}{c}{ Process } & Mineral & Synthetic & Biodegradable \\
\hline $\begin{array}{l}\text { Exploration, extraction and transport } \\
\text { of the crude oil to Spain }\end{array}$ & Yes & Yes & No \\
\hline Oil refining & Yes & No & No \\
\hline Use of the lubricant oil & Yes & Yes & Yes \\
\hline Transport to the recycling plant & Yes & Yes & Yes \\
\hline Energy used to obtain a secondary product & Yes & Yes & Yes \\
\hline The growth process & No & No & Yes \\
\hline Extraction of seeds & No & No & Yes \\
\hline
\end{tabular}

Some processes were not included in the LCA, because they are associated with the lifetime of the lubricant oil or because their contribution to the global assessment is low compared with those listed previously [21]. These process are:

- The manufacture of the equipment and the infrastructure required for the extraction and transport of crude oil and seeds

- The production of fertilisers, seeds and weed-killers

- Management of the waste produced during the extraction of biodegradable oil

- The energy balance during the extraction of petroleum (e.g., obtaining natural gas and other derivatives of petroleum)

- Link and aggregation of additives in the different types of oil

To perform the study, we defined a functional unit (FU) to be the reference unit that forms the basis for comparisons made between different systems. The FU must be defined in the goals and 
scoping phase of an LCA [22]. For this study, we defined the FU as the amount of mineral, synthetic and biodegradable oil in terms of the energy used in $\mathrm{kWh} / \mathrm{l}$, the associated $\mathrm{CO}_{2}$ emissions in terms of $\mathrm{kg} / \mathrm{L}$, and the cost in terms of $€ / \mathrm{L}$ for the Belesar and Velle hydropower plants, and the gearbox of the wind turbine V90-20MW during their lifetime.

\subsection{Hydropower}

The hydropower plants selected for the LCA were Belesar and Velle, located in the Miño-Sil River basin (a heavily intervened catchment [23]) in the northwest of the Iberian Peninsula. Belesar is located at longitude $7.74 \mathrm{~W}$ and latitude $42.66 \mathrm{~N}$. Velle is located downstream at longitude $7.85 \mathrm{~W}$ and latitude $42.36 \mathrm{~N}$. Both plants are managed by Naturgy. Belesar has $310 \mathrm{MW}$ of installed power generation capacity with three Francis turbines, which need $57,800 \mathrm{~L}$ of oil for lubrication and regulation. Velle has 86.5 MW of installed capacity with two Kaplan turbines, and, of the hydropower plants managed by Naturgy it uses the greatest amount of lubricant oil, 70,200 L. In both hydropower plants, the mineral oil used is "Cepsa HD turbines 68". The lifetime of this type of hydropower plant is between 40 and 80 years [24], depending on the type of dam and its construction. For the purposes of our study, we considered a lifetime of 50 years. Belesar and Velle became operational in 1963 and 1967, respectively. Belesar was refurbished between 2007 and 2009, and Velle between 2012 and 2014 [12].

Table 3 shows the mineral oil requirements of Belesar and Velle and Table 4 shows the mineral oil consumption for 2013-2017, together with the mean consumption for the period and extrapolated values for the lifetime of the hydropower plant (50 years).

Table 3. Capacity of the mineral oil Cepsa HD Turbinas 68 in Belesar and Velle hydropower plants.

\begin{tabular}{lccc}
\hline & Lubrication Oil (L) & Regulation Oil (L) & Total (L) \\
\hline Belesar & 27,600 & 30,200 & 57,800 \\
\hline Velle & 14,200 & 56,000 & 70,200 \\
\hline
\end{tabular}

Table 4. Consumption (in litres) of the mineral oil Cepsa HD Turbinas 68 in Belesar and Velle hydropower plants.

\begin{tabular}{lccccccc}
\hline & $\mathbf{2 0 1 3}$ & $\mathbf{2 0 1 4}$ & $\mathbf{2 0 1 5}$ & $\mathbf{2 0 1 6}$ & $\mathbf{2 0 1 7}$ & Mean & Accumulate 50 Years \\
\hline Belesar & 0 & 1665 & 1110 & 1295 & 945 & 1003 & 50,150 \\
\hline Velle & 1480 & 1850 & 0 & 2405 & 0 & 851 & 42,550 \\
\hline
\end{tabular}

\subsection{Wind}

Naturgy has 1012 MW of installed wind power capacity in Spain, with a total of 1227 turbines. In México and Australia, Naturgy has 330 MW with 145 wind turbines [12]. For this study, we selected the VESTAS V90-2MW model of wind turbine, being the one most commonly used by Naturgy and broadly adopted in the market. The VESTAS V90-2MW contains a gearbox that requires $400 \mathrm{~L}$ of lubricant oil to operate. The oil used by Naturgy in this type of wind turbine is the synthetic "Cepsa Aerogear Synt 320". The regulation for wind turbines set out in UNE-EN 61400-1:2006 [25] indicates a number of different characteristics including design, installation, operation and maintenance under specific environmental conditions and offers a range of values for the lifetime of these turbines. According to these regulations, the Spanish Association for Standardization and Certification (AENOR) [26] indicates a lifetime of 20 years accounting for fatigue. The main mechanical component of the wind turbine is the gearbox. We evaluated the lubrication of the gearbox, which has an average expected life of seven years [27]. It is therefore necessary to make three complete changes of lubricant oil in the gearbox during the lifetime of the wind turbine. Consumption data for the synthetic oil "Cepsa Aerogear Synt 320" used in the VESTAS V90-2MW turbine in several wind farms owned by Naturgy are shown in Table 5. 
Table 5. Consumption of synthetic oil Cepsa Aerogear Synt 320 in the gearbox of the wind turbine V90-2MW for 2016-2018 in different wind farms in Spain.

\begin{tabular}{lccc}
\hline & \multicolumn{3}{c}{ Consumption in the Gearbox (L) } \\
\hline Wind Farm & $\mathbf{2 0 1 6}$ & $\mathbf{2 0 1 7}$ & $\mathbf{2 0 1 8}$ \\
\hline Loma Gorda & 486 & 324 & 1510 \\
\hline Peña I & 144 & 126 & 600 \\
\hline San Gil & 486 & 558 & 710 \\
\hline Malagón I & 774 & 2160 & 2740 \\
\hline Malagón II & 522 & 1350 & 2060 \\
\hline Valdelacasa & 63 & 27 & 0 \\
\hline Valdelín & 109 & 54 & 190 \\
\hline Valdelín amp & 44 & 27 & 0 \\
\hline Valdepero & 828 & 108 & 1680 \\
\hline
\end{tabular}

The annual mean consumption (last twenty years) of oil (127 wind turbines) is calculated following the steps set out in Appendix A.1. The mean annual consumption of oil in these 127 wind turbines is $13,513 \mathrm{~L} /$ year, and for each wind turbine the figure is $106.4 \mathrm{~L} /$ year.

\subsection{Energy Consumption and Associated Emissions during the Production of Mineral Oil}

Here, we split the analysis of the production in three steps: extraction, transport and production in the refinery. Table 6 shows the values of the energy used in the extraction and transport of crude oil according to widely adopted practice [21].

Table 6. Energy used in the extraction and transport of crude oil.

\begin{tabular}{lc}
\hline & $\begin{array}{l}\text { Energy Used } \\
\mathbf{( k W h / k g ~ C r u d e ~ O i l ) ~}\end{array}$ \\
\hline Extraction & 0.74 \\
Transport & 0.30 \\
Total & 1.04 \\
\hline
\end{tabular}

For each $\mathrm{kg}$ of crude oil, less than $2 \%$ is used for the production of mineral oil [13]. For this reason, the energy used to produce a $\mathrm{kg}$ of mineral oil is $2 \%$ of the total value in Table 6, i.e., $0.021 \mathrm{kWh} / \mathrm{kg}$. The energy used to obtain it is $10.15 \mathrm{kWh} / \mathrm{L}$ (the data for oil refining were provided by the Spanish Research Centre for Energy, Environment and Technology (CIEMAT) [28]. These data were obtained from the refinery in Algeciras in Cádiz, because this is the biggest refinery in Spain).

The emissions associated with the production of mineral oil were computed using the emissions calculator of the Ministry for the Ecological Transition [29]. The emission factor for converting $\mathrm{kWh}$ to $\mathrm{kgCO}_{2}$ is 0.385 . The associated emissions are thus: $10.15 \mathrm{kWh} / \mathrm{L} \times 0.385=3.91 \mathrm{kgCO}_{2} / \mathrm{L}$. The emissions resulting from extraction and transport are insignificant compared with those related to the energy used in the manufacturing of the oil.

\subsection{Data on Energy and Associated Emissions for the Production of Biodegradable Oil}

Data on the energy and emissions involved in the use of biodegradable oil with a vegetable base were obtained from sources related to colza and sunflower farming [30]. According to published data on the energy values related to the production of colza [31-33], the value is $2131 \mathrm{MJ} / \mathrm{t}$. For the case of sunflower oil, the value is higher, at $4365 \mathrm{MJ} / \mathrm{t}$ [32]. These values include the energy required to transport the crop from farms to extraction plants. Data on the energy necessary to process the colza and sunflower oil were obtained from Group Bunge-Ibérica [34], as shown in Table 7. 
Table 7. Energy used in the growing and processing of biodegradable oil.

\begin{tabular}{lcc}
\hline & $\begin{array}{c}\text { Colza } \\
(\mathbf{M J} / \mathbf{k g})\end{array}$ & $\begin{array}{c}\text { Sunflower } \\
(\mathbf{M J} / \mathbf{k g})\end{array}$ \\
\hline Energy for growing the raw materials & 9.62 & 8.30 \\
Energy for processing oil & 16.55 & 7.34 \\
Total energy & 26.17 & 15.64 \\
\hline
\end{tabular}

In this study, we used the average of the values obtained for the two oils, colza and sunflower, which was $20.90 \mathrm{MJ} / \mathrm{kg}$. This result was then converted into $\mathrm{kWh}$ per litre of oil produced: $6.37 \mathrm{kWh} / \mathrm{L}$. The emissions produced per litre of biodegradable oil were obtained using the calculator of MITECO [29].The conversion factor from $\mathrm{kWh}$ to $\mathrm{kgCO}_{2}$ is 0.385 , meaning that the associated emissions are 2.45 $\mathrm{kgCO}_{2} / \mathrm{L}$.

\subsection{Data on Energy and Associated Emissions for the Production of Synthetic Oil}

We used a specific type of synthetic oil broadly adopted in the energy production sector: Cepsa Aerogear synt 320. This oil has a basis of polyalphaolefins (PAOS) and ester. The synthetic ester comes from fatty acid and alcohol [35], and PAOS are obtained from ethylene. Ethylene is obtained from refineries or natural gas. For these reasons, in the assessment for the production of synthetic oil, we considered a value halfway between those used for mineral and biodegradable oil, as shown in Table 8 . The emissions associated with energy used in terms of $\mathrm{kgCO}_{2}$ are $3.18 \pm 0.73 \mathrm{kgCO}_{2} / \mathrm{L}$.

Table 8. Energy and emissions corresponding to the different types of oil. For the case of synthetic oil, the maximum and minimum biases are shown due to considering its value halfway between mineral and biodegradable.

\begin{tabular}{lccc}
\hline & $\begin{array}{c}\text { Mineral } \\
\text { Oil }\end{array}$ & $\begin{array}{c}\text { Biodegradable } \\
\text { Oil }\end{array}$ & $\begin{array}{c}\text { Synthetic } \\
\text { Oil }\end{array}$ \\
\hline $\begin{array}{l}\text { Energy for each litre produced } \\
\mathbf{k W h} / \mathrm{L}\end{array}$ & 10.15 & 6.37 & $8.26 \pm 1.89$ \\
\hline $\begin{array}{l}\text { Emissions for each litre produced } \\
\mathrm{kgCO}_{2} / \mathrm{L}\end{array}$ & 3.91 & 2.45 & $3.18 \pm 0.73$ \\
\hline
\end{tabular}

\subsection{Data on Energy and Associated Emissions Associated to the Transport and Recycling of Lubricant Oil}

In calculating the energy use and emissions produced during the transport and recycling of the lubricant oil, we considered hydropower plants and wind farms to follow a similar process in terms of receiving and recycling the oil. The data for this were obtained from SIGAUS [36]. The data obtained for the trip to the recycling plant can be seen in Table 9, which shows the average trip length for three different scenarios. In this study, we selected the average of these three types of trips.

Table 9. Average distance to the recycling plant.

\begin{tabular}{cccc}
\hline Metropolitan/Industrial Area & Remote Point & Rest of Municipality & Average \\
\hline $57.1 \mathrm{~km}$ & $97.3 \mathrm{~km}$ & $93.8 \mathrm{~km}$ & $\mathbf{8 7 . 2} \mathbf{~ k m}$ \\
\hline
\end{tabular}

Assuming each truck has a diesel engine and makes urban trips, the emission factor is $490.73 \mathrm{gCO}_{2} / \mathrm{km}$ [37]. The emissions of $\mathrm{CO}_{2}$ are thus the product of $87.2 \mathrm{~km}$ and $490.73 \mathrm{gCO} / \mathrm{km}$, which equates to $42.73 \mathrm{kgCO}_{2}$. The equivalent energy is $110.98 \mathrm{kWh}$, obtained using the calculator of MITECO [29]. The associated emissions per litre are then obtained by dividing the total energy, $110.98 \mathrm{kWh}$, by the number of litres transported each time, $5000 \mathrm{~L}$, giving a result of $0.02 \mathrm{kWh} / \mathrm{L}$. The 
consumption of energy for each kg of recycled oil [19] is 742,000 BTU per barrel of oil used. Thus, the energy used to recycle the oil is $1.35 \mathrm{kWh} / \mathrm{L}$, and after adding the emissions from the associated transport to the recycling plant we obtained $1.37 \mathrm{kWh} / \mathrm{L}$. The associated emissions are $0.53 \mathrm{kgCO}_{2} / \mathrm{L}$ (see Appendix A.2).

2.7. Comparison of Energy and Emissions for the Manufacture, Transport and Recycling Stages in the Use of the Lubricant Oil

For the purpose of this comparison, we take the data in Table 8 and Appendix A.2.

Figures 1 and 2 also summarise the energy requirements and the associated emissions involved in producing one litre of biodegradable, mineral and synthetic oil.

\section{Energy kWh/l}

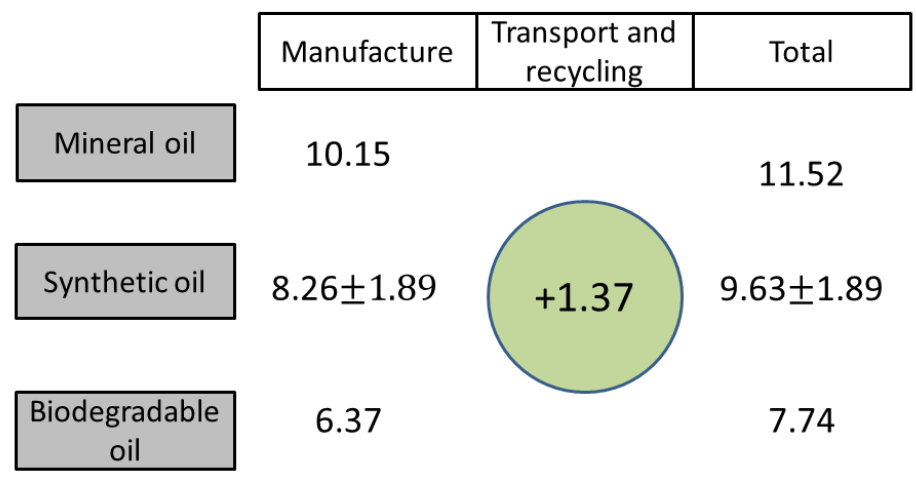

Figure 1. Inputs and outputs in terms of $\mathrm{kWh}$ for each litre of mineral, synthetic and biodegradable oil produced related to their manufacture, transport and recycling.

\section{Emissions $\mathrm{kgCO}_{2} / \mathrm{I}$}

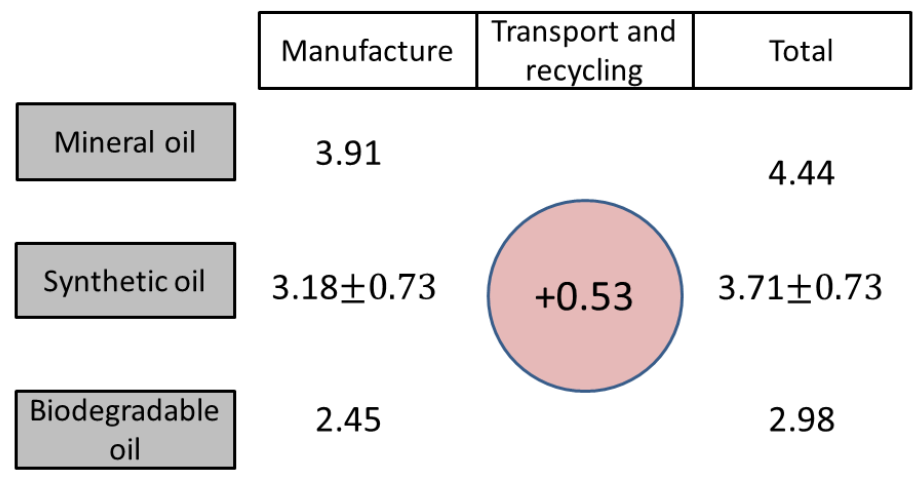

Figure 2. Inputs and outputs in terms of $\mathrm{kgCO}_{2}$ for each litre of mineral, synthetic and biodegradable oil produced related to their manufacture, transport and recycling. 
From an environmental point of view, the production of biodegradable oil uses $33 \%$ less energy than mineral oil and proportionally less $\mathrm{CO}_{2}$ per litre. However, its use is sub-optimal in that the biodegradable oil does not maintain the proper lubrication of the machinery for as long as mineral or synthetic oil [38].

\subsection{Economic Data of Lubricant Oils.}

An economic analysis allows comparisons to be made between the different types of oils used by Naturgy. The price per litre in each case is shown in Table 10.

Table 10. Cost of each litre of lubricant oil used by Naturgy.

\begin{tabular}{lc}
\hline Lubricant Oil & Price $(\boldsymbol{€} / \mathbf{L})$ \\
\hline Cepsa HD Turbinas 68 & 1.34 \\
\hline Cepsa Aerogear Synt 320 & 7.26 \\
\hline Cepsa Bio oil HM-S 68 & 4.27 \\
\hline
\end{tabular}

Tables 11 and 12 show the economic data for the different types of oils as applied to the hydropower plants of Belesar and Velle.

Table 11. Consumption and cost per litre of oil used in Velle.

\begin{tabular}{lcccc}
\hline \multicolumn{5}{c}{ Velle Hydropower Plant } \\
\hline Oil & Consumption (L/Year) & Price $(€ / \mathrm{L})$ & Price per Turbine (€/L) & Price $€ /$ Year \\
\hline Mineral & 425.5 & 1.34 & 570.17 & 1140.34 \\
\hline Synthetic & 425.5 & 7.26 & 3089.13 & 6178.26 \\
\hline Biodegradable & 425.5 & 4.27 & 1816.89 & 3633.77 \\
\hline
\end{tabular}

Table 12. Consumption and cost per litre of oil used in Belesar.

\begin{tabular}{lcccc}
\hline \multicolumn{5}{c}{ Belesar Hydropower Plant } \\
\hline Oil & Consumption (L/year) & Price $(€ / \mathrm{L})$ & Price per Turbine (€/L) & Price $€ /$ Year \\
\hline Mineral & 334 & 1.34 & 447.56 & 1342.68 \\
\hline Synthetic & 334 & 7.26 & 2424.84 & 7274.52 \\
\hline Biodegradable & 334 & 4.27 & 1426.18 & 4278.54 \\
\hline
\end{tabular}

As a part of this study, we undertook an analysis regarding the cost of replacing the oil in the multiplier (with average life of eight years) using the synthetic oil Castrol Optigear Synthetic 320 at a cost of $14.75 € / \mathrm{L}$, which is double that of the oil Cepsa Aerogear Synt 320 (and currently used by Naturgy in this type of wind turbine). Table 13 shows an assessment of the cost. It was considered that the average life of a gearbox is eight years, and in the table the cost of the gearbox is taken to be the average for a restored gearbox and a new gearbox. In Table 14, we show the cost per year of the lubricant oil Castrol Optigear. 
Table 13. Durability of the gearbox.

\begin{tabular}{lcccc}
\hline & Cost Gearbox $(€)$ & Shelf Life (Years) & Cost $(€ /$ Year) & Difference $(€)$ \\
\hline \multirow{2}{*}{ Aero V90-2MW } & \multirow{2}{*}{162,500} & 7 & $23,214.29$ & \multirow{2}{*}{2901.79} \\
\cline { 2 - 4 } & & 8 & $20,312.50$ & \\
\hline
\end{tabular}

Table 14. Consumption and cost of the oil.

\begin{tabular}{lccc}
\hline Type of Oil & Cost Oil $(€ / L)$ & Consumption Gearbox (L) & Cost oil (€/Year) \\
\hline Castrol Optygear & 14.75 & 103 & 1519.25 \\
\hline
\end{tabular}

The relationship between the energy consumed in the production of the oil and the energy dispatched to the grid provides an assessment that reflects the significance and profitability of these components in power generation. In Figure 3, the relationship is shown between the energy required to produce the oil consumed during a single year for the Belesar and Velle hydropower plants, as well as the wind turbine V90-2MW (kWh/year), and the energy dispatched to the grid (kWh/year).

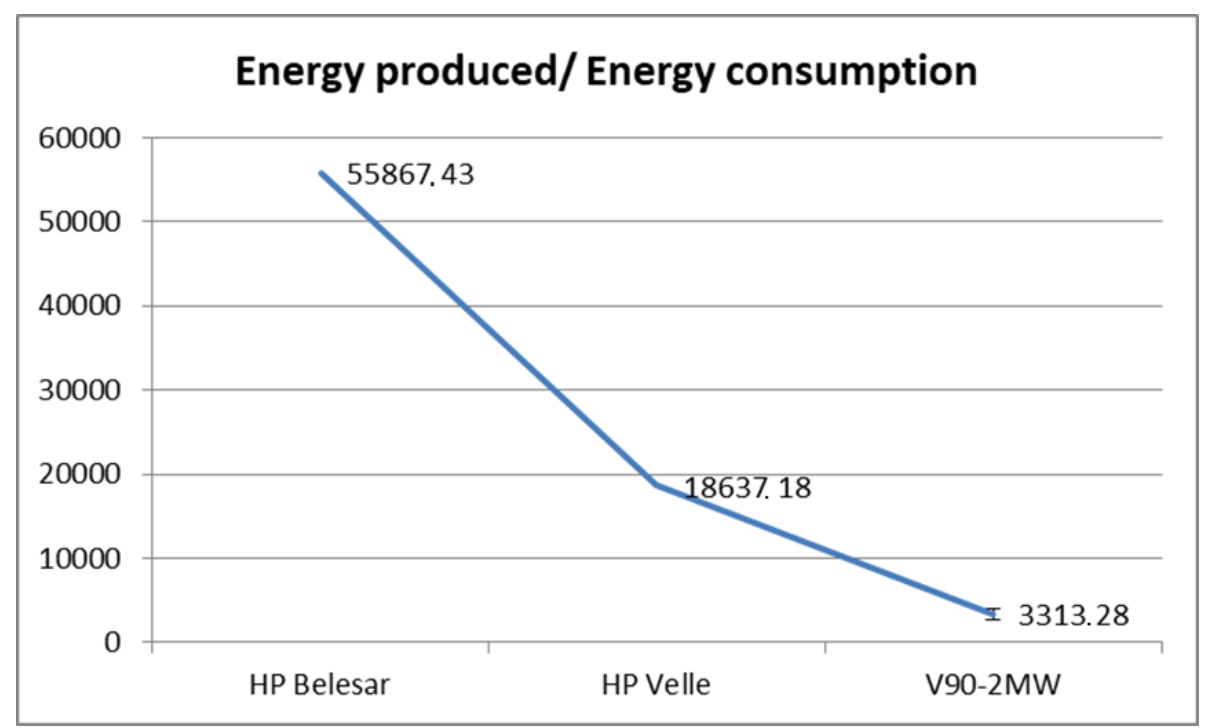

Figure 3. Relationship between the energy dispatched into the grid and the energy required to produce the oil during one year for HP Belesar, HP Velle and the wind turbine V90-2MW. For the case of V90-2MW, we include error bars (although they are almost indiscernible) resulting for the inclusion in the computations of potential bias in the values for the synthetic oil (see Table 8).

\section{Results}

Although the production and use of biodegradable oil emit less $\mathrm{CO}_{2}$, it may not be used in many lubrication systems because it can lose its chemical properties in contact with water. Mineral oil requires the greatest amount of energy for processing and therefore its emissions of $\mathrm{CO}_{2}$ are higher, given that the refining process requires a large amount of energy to convert petroleum to oil (see Figure 4). 


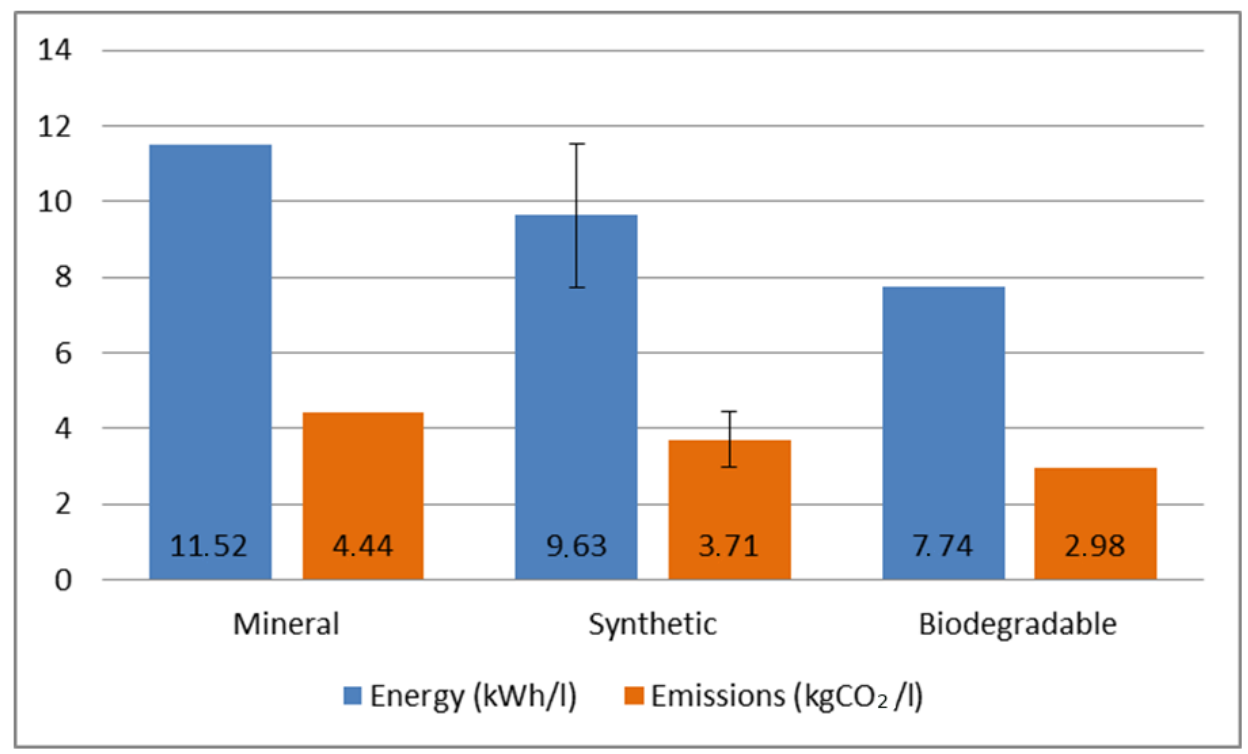

Figure 4. Energy $(\mathrm{kW} / \mathrm{h})$ and emissions $\left(\mathrm{kgCO}_{2}\right)$ for each litre of oil produced for each type of lubricant oils. The error bars for the synthetic oil result from the inclusion in the computations of potential bias (see Table 8).

Using the data for Belesar and Velle hydropower power plants (Tables 11 and 12), we compared the costs to the emissions of $\mathrm{CO}_{2}$ (Figures 5 and 6). Our results show that the use of biodegradable oil instead of mineral oil causes $33 \%$ less $\mathrm{CO}_{2}$ emissions, but the cost is $319 \%$ higher than when using mineral oil.

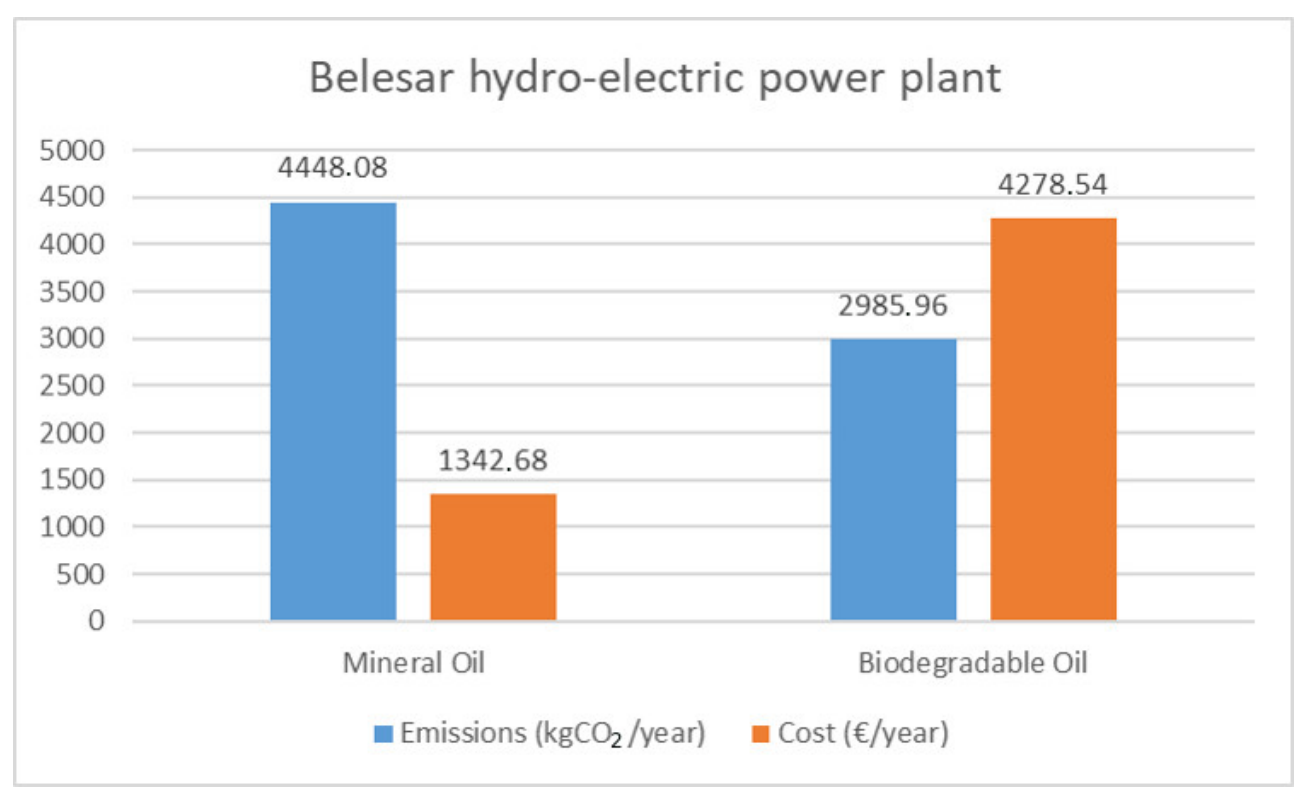

Figure 5. Comparison between mineral oil and biodegradable oil in terms of emissions of $\mathrm{CO}_{2}$ and cost per year for the Belesar hydropower plant. 


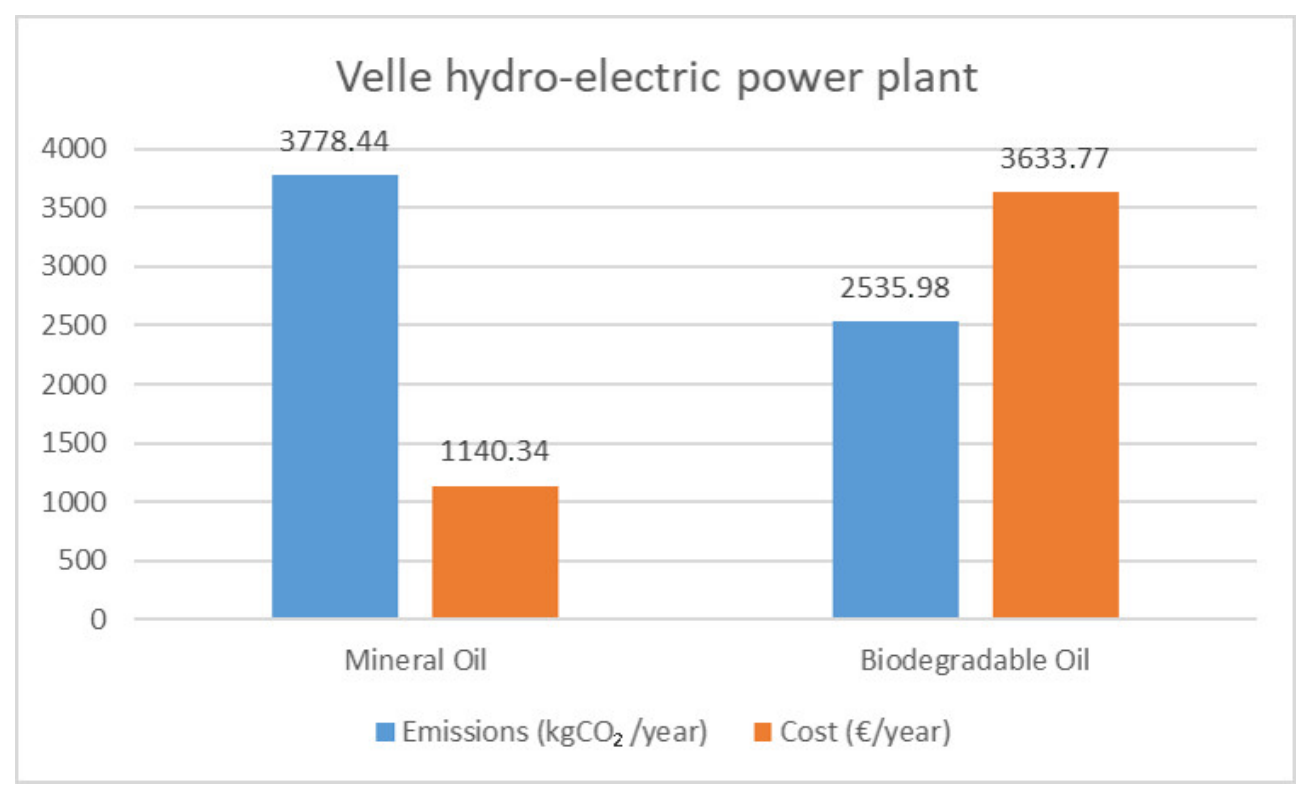

Figure 6. Comparison between mineral oil and biodegradable oil in terms of emissions of $\mathrm{CO}_{2}$ and cost per year for the Velle hydropower plant.

One major disadvantage of biodegradable oil lies in the fact that, on contact water, it degrades more rapidly than mineral oil, losing its essential characteristics and thus affecting the operation of the mechanical plant.

For this reason, the use of biodegradable oil is only necessary for those places in the hydropower plant where there exists a risk of release of oil into the river (i.e., the cleaning grilles and the sluice gate), because in these places there is no retention system in place. For lubrication in the main moving parts of the plant, as long as the cost of biodegradable oil is appreciably higher than that of the mineral oil, hydropower plants will continue to use mineral oil.

As far as the wind turbines are concerned, our analysis yields further useful information. As shown in Tables 13 and 14, it is possible to make an assessment of the durability of the gearbox (of the wind turbine Aero V90-2MW) using the lubricant oil Castrol Optigear. We showed that, if the lifetime of the gearbox can be extended from seven to eight years, i.e., an extra year of operation, it would generate savings of:

$$
2901.79-1519.25=1382.54 €
$$

This result relates to the operation of a single wind turbine. Given that Naturgy currently operates 127 wind turbines of this model (Aero V90-2MW), the total savings could be:

$$
1382.54 \times 127=175,582 €
$$

We note that with these savings comes a potential increase in the durability of the equipment and a decrease in the required frequency of oil changes. These results offer the possibility of environmental benefits, driving innovation and thus more responsible consumption.

Figure 3 shows that for each $\mathrm{kWh}$ necessary to produce the amount of lubricant oil consumed in one year, Belesar HP produces more than 55,000 times more energy, Velle HP produces near to 19,000 times more energy and a single wind turbine V90-2MW produces more than 3300 times energy over the same period of time. Taking into account also that wind power and hydropower do not have associated emissions of $\mathrm{CO}_{2}$, we conclude that there is a clear net gain inherent in the production of lubricant oil with regard to their use in renewable energy. 


\section{Conclusions}

In this study, we analylitered from the environmental, economic, and technical points of view the use of mineral, synthetic, and biodegradable oil in wind and hydropower turbines. Our results show that biodegradable oil (vegetable based) is associated with a small amount of energy (kWh) and has lower equivalent carbon emissions $\left(\mathrm{kgCO}_{2}\right)$ for its manufacture and recycling (33\% less than mineral oil and 20\% lower than the synthetic oil, in terms of both energy and associated emissions in this case).

A comparison between the oils used for wind power (synthetic) and for hydropower (mineral) turbines shows that, per litre, the synthetic oil is five times more expensive for wind than the mineral oil is for hydropower. Furthermore, for wind power, a greater amount of oil is required per GWh. Typically, although mineral oils biodegrade, the processes involved are slow and may be only partial. Biodegradable oils tend to biodegrade more rapidly and more completely $[39,40]$. The use of biodegradable oil in a hydropower plant could entail its more frequent replacement than the use of mineral oil. As shown in Figure 3, just one substitution of the biodegradable oil in the mechanism causes more emissions than the use of mineral oil. Furthermore, the replacement of the oil in the system implies the interruption of energy production during the process. Biodegradable oil is recommended if there is a significant risk of spillage. However, the higher cost of biodegradable vs. natural mineral oil and problems when it comes into contact with water are the main barriers to its wider adoption. For sites where there is no potential for environmental impact during its use, economic considerations carry greater weight than sustainability.

The possible use of other types of synthetic oil in the gearbox of a wind turbine could provide savings up to $1300 €$ per turbine. With this financial incentive, it is recommended for future studies to experiment with other types of synthetic oil, in order to assess properly the assumption of increased durability of the turbine. The evaluation of the lubricant oil from an energy point of view shows particular relevance concerning the energy necessary to produce it and the power released to the grid.

Finally, as a further step in this kind of works in the future, it would be interesting to study the impact on the results of considering a broader range of oils. For example, it would be relevant to evaluate a potential impact on the results here obtained with vegetable-based biodegradable oil when considering instead a biodegradable synthetic oil.

Author Contributions: Conceptualization, G.A.G.-R., J.V.L. and J.A.A.; methodology, G.A.G.-R; validation, G.A.G.-R., J.A.A., J.V.L., S.B-B.; formal analysis, G.A.G.-R. and S.B.-B.; investigation, G.A.G.-R., J.A.A., J.V.L., S.B.-B.; resources, J.A.A. and J.V.L.; data curation, G.A.G.-R. and S.B.-B.; writing-original draft preparation, G.A.G.-R., J.A.A., S.B.-B.; writing-review and editing, G.A.G.-R., J.A.A., J.V.L., S.B.-B.; supervision, J.A.A., J.V.L.; project administration, J.A.A.; funding acquisition, J.A.A. and J.V.L. All authors have read and agreed to the published version of the manuscript.

Funding: This research was funded by the Naturgy Chair at the Universidade de Vigo. EPhysLab is supported by the Xunta de Galicia under the project (D431C 2017/64-GRC “Programa de Consolidación e Estructuración de Unidades de Investigación Competitivas" co-funded by the European Regional Development Fund (ERDF). Juan A. Añel was supported by a "Ramón y Cajal" Grant by the Government of Spain (RYC-2013-14560).

Conflicts of Interest: The authors declare no conflict of interest.

\section{Appendix A}

Appendix A.1. The Annual Mean Consumption (Last Twenty Years) of Oil (127 Turbines) Is Calculated as Follows

For this type of model, the amount of oil used in this gearbox is $400 \mathrm{~L}$.

$$
\text { Total oil }=\text { capacity of gearbox }(\mathrm{L}) \cdot N \text { wind turbines }
$$

$$
\text { Total oil }=400 \mathrm{~L} \cdot 127=50,800 \mathrm{~L}
$$

Total oil without change of gearbox $=N$ years $\cdot$ annual mean 
Total oil without change of gearbox $=20 \cdot 5893 \mathrm{~L}=117,860 \mathrm{~L}$

It was assumed that the change of the oil in the gearbox takes place every seven years [27]; thus,

Total oil changed during the average life of the gearbox $=50,800 \mathrm{~L} \cdot 3=152,400 \mathrm{~L}$

The sum of the total oil used is $=117,860 \mathrm{~L}+152,400 \mathrm{~L}=270,267 \mathrm{~L}$

The mean annual consumption for 127 wind turbines is $=\frac{270,267 \mathrm{~L}}{20 \text { year }}=13,513.31 \frac{\mathrm{L}}{\text { year }}$

Appendix A.2. Energy Consumption and the Emissions Associated to the Transport and Recycling of Lubricant Oil

$$
\begin{gathered}
1 \mathrm{BTU}=1055 \mathrm{~J} \times \frac{1 \mathrm{kWh}}{3.6 \times 10^{6} \mathrm{~J}}=0.00029 \mathrm{kWh} \\
742,000 \frac{\mathrm{BTU}}{\text { barrel }} \times \frac{1 \text { barrel }}{159 \mathrm{~L}} \times \frac{0.00029 \mathrm{kWh}}{1 \mathrm{BTU}}=1.35 \frac{\mathrm{kWh}}{\mathrm{L}}
\end{gathered}
$$

It is necessary to sum the energy associated with the transport between the turbine to the recycling plant:

$$
1.35 \frac{\mathrm{kWh}}{\mathrm{L}}+0.02 \frac{\mathrm{kWh}}{\mathrm{L}}=1.37 \frac{\mathrm{kWh}}{\mathrm{L}}
$$

The emissions associated with the energy are:

$$
1.37 \frac{\mathrm{kWh}}{\mathrm{L}} \times 0.385 \frac{\mathrm{kgCO}_{2}}{\mathrm{kWh}}=0.53 \frac{\mathrm{kgCO}_{2}}{\mathrm{~L}}
$$

\section{References}

1. Spanish Grid. Spanish Electrical System Report 2018; Technical Report; Spanish Grid: Madrid, Spain, 2019.

2. Komusanac, I.; Fraile, D.; Brindley, G. Wind Energy in Europe in 2018. Trends and Statistic; Technical Report; WindEurope: Brussels, Belgium, 2018.

3. Global Wind Energy Council. Global Wind Report 2018; Technical Report; Global Wind Energy Council: Brussels, Belgium, 2019.

4. International Hydropower Assotiation. Hydropower Status Report; Technical Report; International Hydropower Association: London, UK, 2018.

5. Terradillos, J.; Ciria, J.I. All about the Lubrication of the Turbines and Their Maintenance Through Oil Analysis; Technical Report; Wearcheckiberica: Eibar, Spain, 2004. (In Spanish)

6. Fischer, K.; Besnard, F.; Bertling, L. Reliability-Centered Maintenance for Wind Turbines Based on Statistical Analysis and Practical Experience Publisher: IEEE. IEEE Trans. Energy Convers. 2012, 27, 184-195. [CrossRef]

7. Garrett, P.; Ronde, C. Life Cicle Assessment of Electricity Production from a V90-2.0 MW Gridstreamer Wind Plant; Technical Report; Vestas Wind Systems A/S: Randers, Denmark, 2011.

8. Srivastava, S.P. Classification of Lubricants; John Wiley \& Sons: New York, NY, USA, 2014; Chapter 2, pp. 7-21.

9. Marques, P.; Fernandes, C.; Martins, R.; Seabrab, J. Efficiency of a gearbox lubricated with wind turbine gear oils. Tribol. Int. 2014, 71, 7-16. [CrossRef]

10. Wanga, Y.; Sunb, T. Life cycle assessment of $\mathrm{CO}_{2}$ emissions from wind power plants: Methodology and case studies. Renew. Energy 2012, 43, 30-36. [CrossRef]

11. European Environment Agency. Life Cycle Assessment: A Guide to Approaches, Experiences and Information Sources; Technical Report; European Environment Agency: Copenhagen, Denmark, 1998.

12. Naturgy. Available online: www.naturgy.es (accessed on 28 February 2020).

13. CEPSA. Available online: https:/ /www.cepsa.es/es (accessed on 28 February 2020). 
14. VESTAS. Vestas. Available online: https://www.vestas.com/en/products/2-mw-platform/v90-2_0_mw\#! (accessed on 28 February 2020).

15. Spanish Association of Petroleum Products Operators, AOP. Report 2018; Technical Report; Spanish Association of Petroleum Products Operators: Madrid, Spain, 2019. (In Spanish)

16. MITECO ( Ministry of Ecological Transition). Emission Factors; Technical Report; MITECO: Madrid, Spain, 2019. (In Spanish)

17. CORES. Statistic Data: Crude Movement and Disaggregated Production of Refineries; Technical Report; CORES: Madrid, Spain, 2019.

18. SIGAUS. Spanish Management System of Industrial Oil (in Spanish). Available online: http://www.sigaus. es / (accessed on 28 February 2020).

19. Used Oil Re-refining Study to Address Energy Policy Act of 2005. Section 1838; Technical Report; U.S. Department of Energy: Washington, DC, USA, 2006.

20. International Standarization Ortanization (ISO). Environmental Management Life Cycle Assessment Principles and Framework (ISO 14040:2006); ISO: Geneva, Switzerland, 2006.

21. Sheehan, J.; Camobreco, V.; Duffield, J.; Graboski, M.; Graboski, M.; Shapouri, H. Life Cycle Inventory of Biodiesel and Petroleum Diesel for Use in an Urban Bus; Technical Report; National Renewable Energy Laboratory: Golden, CO, USA, 1998. [CrossRef]

22. Meissner Schau, E.; Magerholm Fet, A. LCA Studies of Food Products as Background for EnvironmentalProduct Declarations. Int. J. Life Cycle. Assess. 2008, 13, 255-264. [CrossRef]

23. Añel, J.; Bakhat, M.; Labandeira, X. Hydrological Management of a Heavily Dammed River Basin: The Miño-Sil; Economics for Energy: Vigo, Spain, 2014.

24. IRENA. International Renewable Energy Agency. Renewable Energy Technologies: Cost Analysis Series; Technical Report; IRENA: Abu Dhabi, UAE, 2012.

25. International Standarization Ortanization (ISO). Wind Turbines_Part 1: Design Requirements; ISO: Geneva, Switzerland, 2011.

26. Spanish Standardization Association (AENOR). Available online: https://www.aenor.com/ (accessed on 28 February 2020).

27. Baldwin, B.; Fierro, T.; Fox, J.; Pontius, T. How to Increase the Reliability of the Bearings on the Main Shaft; DYNA (Engineering and Industry): Bilbao, Spain, 2019.

28. CIEMAT (Centre for Energy, Environmental and Technological Research). Life Cicle Assessment of Alternative Fuel for the Transport; Technical Report; Centre of publications (Ministry of Environment): Madrid, Spain, 2006. (In Spanish)

29. Ministry of Ecological Transition. $\mathrm{CO}_{2}$ Calculator for a Company; Ministry of Ecological Transition: Madrid, Spain, 2019. (In Spanish)

30. Ministry of Agriculture Fishing and Food of Spain. Cultivated Area in Spain of Oil Plants. 2019. Available online: https: / www.mapa.gob.es/es/agricultura/temas / producciones-agricolas/cultivos-herbaceos / leguminosas-y-oleaginosas / (accessed on 28 February 2020).

31. Ceuterick, D.; Spirinckx, C.; Torfs, R. Comparative LCA of Biodiesel and Fossil Fuel Diesel; Vlaamse Instelling voor Technologisch Onderzoek (VITO): Boeretang, Belgium, 1997.

32. Price Waterhouse Coopers. Energy and Greenhouse Gas Balance Sheets for Biofuel Production; Technical Report; Price Waterhouse Coopers: Ottawa, ON, Canada, 2002.

33. Nielsen, P.; Nielsen, A.; Weidema, B.; Dalgaard, R.; Halberg, N. LCA food database. 2003. Available online: http:/ / www.lcafood.dk/ (accessed on 20 May 2020)

34. Bunge Ibérica. Available online: https://www.bungeiberica.com/bungeKC/Home.action (accessed on 28 February 2020).

35. Peterson, A. High-performance base fluids for environmentally adapted lubricants. Tribol. Int. 2007, 40, 638-645. [CrossRef]

36. SIGAUS. Sigaus News. The Used Oil in Spain; Technical Report 24; SIGAUS: Madrid, Spain, 2017. (In Spanish)

37. Catalan Office for Climate Change. Practical Guide for Calculating Greenhouse Gas Emissions; Technical Report; Catalan Office for Climate Change: Barcelona, Spain, 2019. (In Catalan)

38. Wittenbrink, R.; Bauman, R.; Ryan, D. Biodegradable High Performance Hydrocarbon Base Oils. U.S. Patent US6096940A, 1 August 2000. 
39. Aluyor, E.; Obahiagbon, K.O.; Mudiakeoghene, O. Biodegradation of vegetable oils: A review. Sci. Res. Essays 2009, 4, 543-548.

40. Battersby, N. The biodegradability and microbial toxicity testing of lubricants— Some recommendations. Chemosphere 2000, 41, 1011-1027. [CrossRef] 